Jurnal Akuntansi dan Investasi, Vol. 18 No. 1, Hlm: 66-79, Januari 2017

Artikel ini tersedia di website: http://journal.umy.ac.id/index.php/ai

DOI: $10.18196 /$ jai.18161

\title{
Pengaruh Volatilitas Laba, Perataan Laba dan Corporate Governance terhadap Kualitas Laba Bank Syariah dan Konvensional
}

Rahma Wijayanti* \& Vera Diyanty

Pascasarjana Ilmu Akuntansi Universitas Indonesia, Depok, Indonesia

\begin{tabular}{l}
\hline A R T I C L E I N F O \\
\hline Article history: \\
received 15 Mar 2016 \\
revised 31 Okt 2016 \\
accepted 16 Nov 2016 \\
\\
Keywords: \\
Quality; Earnings \\
Volatility; Income \\
Smoothing; Corporate \\
Governance
\end{tabular}

\begin{abstract}
A B S TRACT
This study examines earnings quality and the effects of Corporate Governance (CG) towards earnings quality in Islamic and Conventional Banks. Earnings quality in this study analyzed by investigating earnings volatility that affect the predictability of earnings and by detecting income smoothing using loan loss provision. Bank's earnings volatility predicted to increase because the financial instruments are reported using fair value method after PSAK 50/55 revision. Previous studies report that bank's manager use their accrual discretion to manage earnings volatility by smooth their income. Using samples of Islamic and conventional banks from period 2007-2014 and pooled least square method, this study finds that earnings volatility only significant in conventional banks's acccrual discretion. Earnings volatility has no effect on Islamic banks's accrual discretion. However, the income smoothing is significant in Islamic and conventional banks. CG mechanism which is measured using self-assessment scores proven to weaken the income smoothing on both banks. This study also finds that difference in CG self-assessment mean value score is significant on both banks.
\end{abstract}

(C) 2017 JAI. All rights reserved

\section{PENDAHULUAN}

Sektor perbankan di Indonesia mengalami perkembangan yang cukup baik. Sesuai dengan data statistik Otoritas Jasa Keuangan (OJK), kondisi perbankan Indonesia dalam keadaan stabil, terlihat dari ekspansi usaha bank yang meningkat 4,35\% per tahun dan rasio kecukupan modal yang menunjukkan angka cukup tinggi sebesar 19,51\% pada tahun 2014. Memasuki dua dekade eksistensi perbankan syariah dalam industri perbankan nasional, OJK mencatat terdapat pertumbuhan yang menggembirakan pada perbankan syariah. Menurut laporan statistik OJK tahun 2014, pada akhir tahun 2009 hanya ada 6 (enam) Bank Umum Syariah dengan 711 kantor cabang. Di akhir tahun 2015, terdapat 12 Bank Umum Syariah dengan lebih dari 2.000 kantor cabang. Namun demikian, selama masa eksistensinya, market share perbankan syariah tidak pernah melebihi 5\% dari total aset perbankan nasional (Road Map Perbankan Syariah, OJK, 2014-2019).
Dalam Road Map Perbankan Syariah 20142019, OJK menyebutkan bahwa rendahnya market share ini disebabkan lemahnya daya saing bank syariah terhadap bank konvensional. Selain itu, Laela (2012) juga menambahkan jika rendahnya market share perbankan syariah ini disebabkan oleh rendahnya minat masyarakat menabung dan berinvestasi, serta menjadikan bank syariah sebagai sumber pembiayaan bisnis. Keengganan masyarakat menjadikan bank syariah sebagai tempat berinvestasi dan juga sebagai partner bisnis tentunya memiliki penyebab. Keterbatasan dalam pilihan investasi dan akses yang terbatas pada jenis transaksi antar bank yang bebas bunga menimbulkan tantangan bagi manajer bank syariah dalam menjaga tingkat modal dan tingkat risiko likuiditas (Elnahass et al., 2013). Menurut Laela (2012), sistem bagi hasil yang dijalankan oleh bank syariah membuat tingkat risiko yang dihadapi semakin meningkat. Manajer bank syariah harus menjaga tingkat pengembalilan tetap menguntungkan bagi nasabah, namun juga tetap harus memperhitungkan kemungkinan terjadinya rugi dari pembiayaan yang disalurkan. 
Sebagai dasar perhitungan pembagian keuntungan pada kontrak bagi hasil, maka informasi atas profit atau laba menjadi suatu hal yang penting. Dengan demikian, kualitas atas laba yang dijadikan sebagai acuan pembagi keuntungan menjadi hal yang harus diperhatikan. Hal inilah yang menjadi motivasi dilakukannya penelitian ini. Penelitian ini berusaha menginvestigasi faktor yang berpengaruh terhadap kualitas laba bank. Pada penelitian ini kualitas laba bank dianalisis dengan prediktabilitas dan perataan laba. Penelitian-penelitian terdahulu mengenai kualitas laba menyimpulkan jika prediktabilitas laba dan perataan laba (income smoothing) adalah faktorfaktor yang mempengaruhi kualitas laba (Dechow et al., 2004; Lo, 2008; Dechow et al., 2010; Clubb dan Wu, 2012).

Prediktabilitas laba dalam penelitian ini dianalisis dengan menginvestigasi volatilitas laba yang dapat mempengaruhi keakuratan prediksi laba oleh pengguna laporan keuangan (DeFond dan Hung, 2003; Dichev dan Tang 2006). Volatilitas laba pada sektor perbankan diprediksi meningkat akibat adanya revisi pada PSAK 50/55 (revisi 2011) yang mewajibkan pelaporan instrumen keuangan menggunakan nilai wajar. Institusi perbankan mengalami dampak volatilitas laba yang cukup besar karena sebagian besar aset dan liabilitas pada bank merupakan instrumen keuangan (Adzis, 2012). Untuk mengatasi dampak dari volatilitas laba tersebut, manajer bank diduga menggunakan diskresi berupa perataan laba untuk menghasilkan laba yang lebih stabil (Wahlen, 1994).

Dugaan adanya income smoothing dalam penelitian ini dianalisis dengan menginvestigasi penggunaan loan loss provision (LLP) yang digunakan sebagai cara perataan laba. Penelitian terdahulu menyebutkan jika LLP adalah cara yang paling sering digunakan sebagai cara perataan laba di sektor perbankan, termasuk juga perbankan syariah (Wahlen, 1994; Kim dan Kross 1998; Anandarajan et al., 2006; Taktak et al., 2010; Bushman dan Williams 2012; Farook et al., 2014; Othman dan Mersni 2014). Laela (2012) berpendapat bank syariah melakukan perataan laba guna mendapatkan return nasabah yang kompetitif dengan bank konvensional.

Penelitian ini juga menganalisis peranan Corporate Governance (CG) dalam memoderasi tingkat prediktabilitas laba dan manajemen laba. Bhat et al. (1995), Jiang et al. (2008) dan Laela (2012) menyatakan jika mekanisme CG yang semakin baik dapat meningkatkan kemampuan prediktabilitas laba. Hal ini disebabkan peningkatan transparansi dalam pelaporan keuangan yang meningkatkan akurasi pengambilan keputusan dari pengguna laporan keuangan. Mekanisme CG yang semakin baik juga terbukti memperlemah manajemen laba (Laela, 2012; Oktaviyanti, 2013). Mekanisme CG dalam penelitian ini diukur menggunakan skor self-assessment pelaksanaan CG oleh bank umum. Skor ini diharapkan dapat merefleksikan pelaksanaan CG secara komprehensif di sektor perbankan. Hal ini dimungkinkan karena menurut SE BI No.15/15/DPNP tahun 2013, dalam skor ini terdapat penilaian komprehensif atas governance structure, governance process, dan governance outcome di sektor perbankan.

Penelitian ini penting untuk dilakukan disebabkan investigasi atas dampak volatilitas laba dan dugaan adanya diskresi manajemen melakukan perataan laba di perbankan syariah belum banyak dilakukan. Penelitian Laela (2012) menggunakan kekuatan laba saat ini (current operating income) untuk memprediksi arus kas masa depan. Namun penelitian Laela (2012) tidak berhasil membuktikan jika laba operasi dapat digunakan untuk memprediksi arus kas masa depan. Oleh karena itu, penelitian ini menggunakan proxy prediktabilitas laba berupa volatilitas laba yang menurut penelitian terdahulu dapat mempengaruhi akurasi prediktabilitas laba pada sektor perbankan. Selain itu, penelitian ini juga menambahkan investigasi mengenai dugaan perataan laba yang juga dapat mempengaruhi kualitas laba dan peran CG dalam memperlemah tindakan perataan laba.

\section{TINJAUAN LITERATUR DAN PERUMUSAN HIPOTESIS}

\section{Corporate Governance dan Self-Assessment CG di Sektor Perbankan}

Bank Indonesia menetapkan jika Good Corporate Governance (GCG) merupakan salah satu faktor yang dinilai dalam penilaian tingkat kesehatan bank umum. Tingkat kesehatan ini dinilai berdasarkan risiko yang dihadapi perbankan. Dalam melaksanakan ketentuan ini, seluruh bank umum diwajibkan melakukan self-assessment terhadap pelaksanaan tata kelola perusahaan (GCG) seperti yang diatur dalam Surat Edaran Bank Indonesia No.15/15/DPNP tahun 2013. 
Sesuai dengan SE BI No.15/15/DPNP tahun 2013, self-assessment pelaksanaan GCG dilakukan secara komprehensif dan terstruktur dengan mengintegrasikan faktor-faktor penilaian ke dalam 3 (tiga) aspek governance, yaitu governance structure, governance process, dan governance outcome. Penilaian sendiri (self-assessment) pelaksanaan GCG dilakukan terhadap 11 faktor penilaian pelaksanaan GCG, yaitu: pelaksanaan tugas dan tanggung jawab dewan komisaris; pelaksanaan tugas dan tanggung jawab direksi; kelengkapan dan pelaksanaan tugas komite; penanganan benturan kepentingan; penerapan fungsi kepatuhan; penerapan fungsi audit intern; penerapan fungsi audit ekstern; penerapan manajemen risiko termasuk sistem pengendalian intern; penyediaan dana kepada pihak terkait (related party) dan penyediaan dana besar (large exposures); transparansi kondisi keuangan dan non keuangan bank, laporan pelaksanaan GCG, dan pelaporan internal; dan rencana strategis bank.

Sebelas item penilaian ini memiliki bobot yang berbeda. Setiap item memiliki faktor berbeda yang dilakukan pemeringkatan sesuai dengan tata kelola (CG) yang dilaksanakan. Peringkat ini kemudian dikalikan dengan bobot untuk memperoleh skor setiap item. Skor ini kemudian dijumlahkan untuk mengetahui nilai komposit. Nilai komposit ini memiliki peringkat yang ditetapkan dalam 5 (lima) peringkat, yaitu Peringkat 1 sangat baik, Peringkat 2 baik, Peringkat 3 cukup baik, Peringkat 4 kurang baik, dan Peringkat 5 tidak baik. Nilai komposit dan urutan peringkat faktor GCG yang lebih kecil mencerminkan penerapan GCG yang lebih baik.

Dalam hal pelaksanaan self-assessment GCG ini, bank umum syariah pun diwajibkan mematuhi peraturan ini. Menurut Laela (2012), hal yang membedakan struktur tata kelola bank syariah dan bank konvensional adalah keberadaan Dewan Pengawas Syariah (DPS) sebagai mekanisme pengawasan dan kepatuhan terhadap operasional bisnis berdasarkan prinsip syariah. Menurut Surat Edaran BI No.8/19/DPbS tahun 2006, DPS bertugas menilai aspek syariah terhadap pedoman operasional dan produk yang dikeluarkan bank; memberikan opini dari aspek syariah terhadap pelaksanaan operasional bank secara keseluruhan dalam laporan publikasi bank; mengkaji produk dan jasa baru yang belum memiliki fatwa untuk dimintakan fatwa kepada DSN; dan menyampaikan laporan hasil pengawasan syariah. Dalam kaitannya dengan self-assessment GCG antara bank konvensional dan bank syariah, terdapat perbedaan item penilaian pada kedua bank tersebut. Perbedaan tersebut terdapat pada "Pelaksanaan tugas dan tanggung jawab dewan pengawas syariah" dan "Pelaksanaan prinsip syariah dalam kegiatan penghimpunan dan penyaluran dana serta pelayanan jasa” (Laela, 2012).

\section{Pengaruh Volatilitas Laba pada Diskresi Manajemen di Sektor Perbankan}

Volatilitas laba menunjukkan tingkat fluktuasi laba yang diperoleh bank dari kegiatan operasionalnya selama beberapa periode. Volatilitas laba juga menunjukkan tingkat risiko yang tercermin dari besarnya simpangan atas tinggi rendahnya laba yang diperoleh bank selama periode tertentu. Semakin besar simpangan, semakin tinggi volatilitas laba, yang berarti juga semakin besar risiko yang dimiliki bank (Oktaviyanti, 2013). Penelitian Haan dan Poghosiyan (2012) yang menggunakan variasi dari Return on Asset (ROA) untuk menghitung volatilitas laba bank selama periode tertentu, membuktikan jika bank dengan ukuran aset yang besar memiliki volatilitas laba yang lebih rendah dibandingkan dengan bank dengan ukuran aset yang kecil.

Menurut DeFond dan Hung (2003), Dichev dan Tang (2006) dan Clubb dan Wu (2012) volatilitas laba yang semakin besar akan menurunkan kualitas laba yang dilaporkan. Hal ini disebabkan laba yang cenderung berfluktuasi akan menyulitkan pengguna laporan keuangan dalam memprediksi laba perusahaan di masa depan. Estimasi laba dapat menjadi bias dan menjadi tidak akurat pada kondisi laba yang berfluktuasi. Laba yang stabil adalah hal yang penting bagi bank, karena volatilitas laba yang tinggi pada satu bank dapat menimbulkan efek domino, volatilitas laba yang tinggi menyebabkan kinerja bank menurun dan berdampak pada aspek lain, seperti meningkatnya risiko likuiditas dan reputasi bank. Oleh karena itu, manajer di sektor perbankan dan regulator memiliki kepentingan untuk menjaga volatilitas laba minimum pada bank (Farook et al., 2014).

Penelitian Untoro (2012), Anggraita (2012) dan Oktaviyanti (2013) menemukan bukti jika volatilitas laba di sektor perbankan meningkat setelah diterapkannya revisi pada PSAK 50/55 (revisi 2011). Hal ini disebabkan revisi pada PSAK 50/55 (revisi 2011) mewajibkan bank menggunakan akuntansi nilai wajar (fair value) untuk mengukur dan melaporkan instrumen keuangan. Institusi perbankan mengalami dampak 
yang cukup besar karena sebagian besar aset dan liabilitas pada bank merupakan instrumen keuangan (Adzis, 2012). Penelitian yang dilakukan Barth et al. (1995), menemukan bukti jika bank dengan laba yang dihasilkan melalui metode akuntansi menggunakan nilai wajar memiliki volatilitas laba yang lebih tinggi jika dibandingkan dengan metode biaya historis.

Suhardiman (2013) menyatakan akad bagi hasil pada bank syariah diprediksi dapat menimbulkan fluktuasi laba. Fluktuasi laba ini disebabkan oleh keterbatasan instrumen keuangan dan investasi yang sesuai dengan prinsip syariah, sehingga bank syariah menghadapi risiko likuiditas. Selain itu, bank syariah selaku penanggung dana (shahibul mal) menanggung risiko pada pembiayaan atas dana yang disalurkan, dimana kerugian seringkali ditanggung oleh bank syariah (Laela, 2012; Suhardiman, 2013). Untuk mengatasi dampak dari volatilitas laba tersebut, manajer bank diduga menggunakan diskresinya dalam menggunakan metode dan estimasi kebijakan akuntansi untuk mendapatkan laba dengan tingkat fluktuasi yang stabil (Bartov, 1993; Wahlen, 1994; McVay, 2006; Farook et al., 2014). Menurut Untoro (2012), Anggraita (2012) dan Oktaviyanti (2013), diskresi manajemen ini dilakukan melalui penentuan besaran nilai cadangan kerugian penurunan nilai (CKPN). CKPN adalah cerminan penetapan risiko default kredit/pembiayaan di masa depan. Risiko default kredit ini diantisipasi dengan cara membentuk cadangan risiko kredit macet di masa sekarang. Jika diprediksi risiko meningkat, maka cadangan yang dibentuk juga akan semakin besar (Oktaviyanti, 2013).

Berdasarkan penelitian terdahulu, volatilitas laba diprediksi meningkatkan risiko bagi bank. Untuk mengatasi hal tersebut, diduga manajer bank menggunakan diskresinya dalam penentuan besarnya nilai CKPN sebagai cerminan antisipasi risiko default kredit di masa depan. Berdasarkan hal itu, maka dinyatakan hipotesis sebagai berikut: H1a: Volatilitas laba berpengaruh pada diskresi manajemen dalam penentuan nilai wajar kredit/pembiayaan pada bank konvensional.

H1b: Volatilitas laba berpengaruh pada diskresi manajemen dalam penentuan nilai wajar kredit/pembiayaan pada bank syariah.

\section{Perataan Laba di sektor Perbankan}

Salah satu cara yang digunakan manajer bank untuk mengatasi volatilitas laba adalah melakukan perataan laba menggunakan biaya penyisihan kerugian aset produktif (Wahlen, 1994; Kim dan Kross, 1998; Anandarajan, 2006; Taktak et al., 2010; Adzis, 2012; Bushman dan Williams, 2012; Farook et al., 2014; Othman dan Mersni, 2014). Hal ini disebabkan biaya penyisihan kerugian aset produktif (Loan Loss Provision/LLP) merupakan cerminan dari antisipasi kerugian dan pengelolaan risiko atas aset produktif oleh manajer bank (Anandarajan et al., 2006; Haryono, 2008). )

Menurut Wahlen (1994) Loan loss provision merupakan biaya yang dicatat untuk meningkatkan cadangan penyisihan kerugian (Loan Loss Allowance) dan mengurangi laba sebelum pajak periode berjalan. Biaya penyisihan kerugian kredit yang meningkat akan menurunkan besarnya laba bersih yang dilaporkan, sebaliknya penundaan pembebanan biaya penyisihan kerugian akan meningkatkan laba bersih. Pada kondisi laba bank rendah, manajer bank diduga memiliki insentif untuk menunda pembebanan biaya penyisihan kerugian (Untoro, 2012; Oktaviyanti, 2013). Manajer bank memiliki informasi tersendiri terkait dengan risiko gagal bayar pada setiap kredit atau pembiayaan yang diberikan kepada nasabah, sehingga pertimbangan dan diskresi manajer diperlukan untuk mengestimasi besarnya LLP (Wahlen, 1994).

Bank syariah memiliki faktor risiko yang lebih besar dibandingkan dengan bank konvensional. Hal ini disebabkan transaksi bebas bunga membuat jenis dan pilihan investasi yang bisa dilakukan oleh bank syariah lebih sedikit jika dibandingkan dengan bank konvensional (Elnahass et al., 2013; Suhardiman, 2013). Laela (2012) berpendapat jika fluktuasi return yang diperoleh melalui sistem bagi hasil meningkatkan kecenderungan terjadinya moral hazard. Pada kerja sama dengan sistem bagi hasil, terdapat risiko bisnis berupa potensi penyalahgunaan pembiayaan oleh debitur. Bank syariah sebagai pemilik dana (principah) tidak dapat mengendalikan sepenuhnya perilaku debitur (agent) yang pada akhirnya akan meningkatkan potensi gagal bayar (default). Untuk mengatasinya, manajer bank syariah akan mencadangkan laba untuk meratakan tingkat return pada nasabah atau untuk menutupi kerugian.

Dewan Syariah Nasional Majelis Ulama Indonesia (DSN-MUI) mengeluarkan fatwa No. 87/DSN-MUI/XII/2012 mengenai metode perataan penghasilan di bank syariah. Fatwa ini dikeluarkan dengan pertimbangan bahwa bank syariah berada pada kondisi terdapat dugaan kuat meng- 
hadapi risiko pengalihan atau penarikan dana nasabah akibat tingkat imbalan yang tidak kompetitif dan wajar (displaced commercial risk). Oleh karenanya, bank syariah diperbolehkan membuat kebijakan yang dikenal dengan metode perataan pendapatan berupa perataan pendapatan tanpa membentuk cadangan penyesuaian keuntungan, dan perataan pendapatan dengan membentuk cadangan penyesuaian keuntungan (Profit Equalization ReservePER). Penentuan kondisi terdapat risiko pengalihan ini ditentukan oleh manajer bank syariah berdasarkan pedoman operasional bank yang bersangkutan dengan memperhatikan opini DPS. Dengan demikian, manajer bank memiliki kewenangan/diskresi dalam menentukan adanya risiko displaced commercial risk dengan diawasi oleh DPS. Cara perataan laba ini ditempuh agar bank syariah dapat memiliki tingkat pengembalian (return) yang sebanding dengan bank konvensional (Laela, 2012).

Selain untuk mendapatkan tingkat laba yang smooth, perataan laba menurut Cornett et al. (2009) juga dilakukan oleh manajer bank dengan motif mendapatkan bonus. Bank dengan tingkat laba dan modal yang tinggi mencatat cadangan kerugian (loan loss) yang lebih tinggi, terutama pada bank yang menerapkan bonus manajer berbasis kinerja. Hal ini mengindikasikan adanya dugaan manajemen laba akibat manajer ingin melaporkan laba lebih tinggi, sehingga berkesempatan mendapatkan bonus yang lebih besar.

Penelitian Ahmad et al. (1999) menemukan bahwa LLP berpengaruh terhadap laba sebelum pajak. Pada bank syariah, penelitian Taktak et al. (2010) pada bank syariah juga memberikan hasil serupa. Namun, Terdapat juga penelitian yang tidak berhasil menemukan bukti bahwa LLP digunakan sebagai cara perataan laba pada sektor perbankan. Dengan demikian, dapat dikatakan jika hasil penelitian terdahulu mengenai perataan laba perbankan menggunakan LLP belum konklusif. Berdasarkan berbagai penjelasan yang diuraikan, maka hipotesis berkaitan dengan perataan laba menggunakan LLP pada penelitian ini dinyatakan sebagai berikut:

H2a: LLP berpengaruh positif pada perataan laba pada bank konvensional.

H2b: LLP berpengaruh positif pada perataan laba pada bank syariah.

\section{Perataan Laba dan Corporate Governance}

Tingkat kepatuhan yang tercermin dalam pelaksanaan Corporate Governance di bank akan mempengaruhi manajer bank dalam melakukan perataan laba. Semakin besar tingkat kepatuhan, maka potensi untuk melakukan perataan laba akan semakin berkurang (Oktaviyanti, 2013). Skor hasil self-assessment pelaksanaan CG diharapkan mampu merefleksikan pelaksanaan CG perbankan secara komprehensif. Hal ini dimungkinkan karena semua unsur penilaian good Corporate Governance sudah termasuk dalam komponen self-assessment (Laela, 2012). Laela (2012) dan Oktaviyanti (2013) menemukan jika semakin baik peringkat self-assessment pelaksanaan CG, maka semakin rendah tingkat perataan laba yang dilakukan. Berdasarkan penelitian terdahulu, maka hipotesis pelaksanaan CG dengan perataan laba dinyatakan sebagai berikut:

H3: Efektifitas Pelaksanaan CG akan memperlemah perataan laba.

\section{Pelaksanaan Corporate Governance di Bank Syariah dan Bank Konvensional}

Hal mendasar yang membedakan fungsi pengawasan bank syariah dan konvensional adalah adanya fungsi pengawasan tambahan pada bank syariah. Pada bank syariah, terdapat mekanisme pengawasan tambahan, yaitu Dewan Pengawas Syariah (DPS). Dengan demikian, bank syariah memiliki dua board, yaitu Sharia Supervisory Board (SSB) atau Dewan Pengawas Syariah dan Board of Directors (BoD) seperti pada bank umum lainnya (Laela, 2012).

Menurut Surat Edaran Bank Indonesia No. 8/19/DPbS tahun 2006, fungsi DPS adalah memberikan pengawasan dan memberi saran bagi direksi bank agar dapat menjalankan kegiatan operasional sesuai dengan prinsip syariah (sharia compliance). Menurut Laela (2012), dalam sharia compliance, DPS mengawasi dan mengatur aktivitas operasional bank syariah berjalan sesuai dengan etika dan tata nilai Islam. Hal-hal yang diatur meliputi larangan berbuat zalim dan larangan mendistorsi informasi. Selain itu, DPS juga harus memastikan pengalokasian laba/rugi pada investor telah dilaksanakan sesuai dengan hukum Islam. Dengan adanya double board ini, diharapkan tingkat pengawasan terhadap manajer di bank syariah akan meningkat, sehingga pelaksanaan CG di bank syariah diprediksi lebih kuat dalam menurunkan tindakan manajer melakukan perataan laba jika dibandingkan dengan bank konvensional. Berdasarkan hal ini, maka hipotesis berkaitan dengan pelaksanaan CG di bank syariah, dinyatakan sebagai berikut: 
H4: Efektifitas pelaksanaan CG di bank syariah lebih kuat dalam memperlemah perataan laba dibandingkan bank konvensional

\section{METODE PENELITIAN}

\section{Pemilihan Sampel dan Data}

Penelitian ini menggunakan populasi 11 bank umum syariah dan sampel 11 bank konvensional. Untuk mendapatkan komparabilitas yang lebih tinggi, 11 bank konvensional yang menjadi sampel dalam penelitian ini dipilih berdasarkan adanya hubungan induk-anak dengan bank syariah (Laela, 2012). Dengan adanya hubungan induk-anak, bank syariah terlebih dahulu mendapatkan contoh pelaksanaan CG dari bank konvensional, sehingga diharapkan diperoleh tingkat perbandingan yang lebih besar.

\section{Tabel 1. Observasi Penelitian}

\begin{tabular}{lc}
\hline Total laporan keuangan 10 Bank & 67 \\
Umum Syariah (BUS) 2007-2014 & \\
$\begin{array}{l}\text { Laporan keuangan bank umum } \\
\text { konvensional dapat diperbandingkan }\end{array}$ & 71 \\
$\begin{array}{l}\text { Laporan keuangan BUS tidak lengkap } \\
\text { Laporan keuangan bank konvensional } \\
\text { tidak lengkap }\end{array}$ & $(16)$ \\
\hline Total observasi akhir & 116 \\
\hline
\end{tabular}

Data dalam penelitian ini diperoleh melalui laporan tahunan, laporan keuangan, dan laporan pelaksanaan CG yang dipublikasikan bank konvensional dan syariah melalui website masingmasing bank. Periode data yang digunakan dalam penelitian ini adalah tahun 2007-2014. Data laporan keuangan bank umum syariah dan bank konvensional terdiri dari 138 tahun buku. Data mengenai skor hasil self-assessment disajikan sebagai bagian dari laporan tahunan ataupun dalam laporan pelaksanaan CG yang terpisah dari laporan tahunan. Data pada penelitian ini terdiri dari 67 laporan keuangan bank syariah dan 71 laporan keuangan bank konvensional. Dari 67 laporan keuangan bank syariah, terdapat 16 laporan keuangan yang datanya tidak lengkap, sedangkan dari 71 laporan keuangan bank konvensional terdapat 6 laporan keuangan yang tidak lengkap. Banyaknya jumlah observasi yang kurang lengkap pada bank syariah menyebabkan jumlah observasi yang dapat dilakukan semakin berkurang. Data yang kurang lengkap ini terutama disebabkan terdapat bank syariah yang tidak mempublikasikan laporan keuangannya dengan lengkap. Dengan demikian, jumlah akhir tahun buku yang dapat dianalisis sebanyak 116 tahun buku. Pemilihan periode sampel dimulai dari tahun 2007, karena tahun tersebut merupakan periode permulaan kewajiban pelaporan selfassessment pelaksanaan CG bank umum (Laela, 2012). Data mengenai prsedur pemilihan sampel disajikan pada Tabel 1.

\section{Model Empiris dan Pengukuran Variabel}

Diskresi manajer bank dalam penentuan nilai wajar kredit diukur dengan cara menghitung besarnya diskresi dalam penetapan besaran cadangan kerugian penurunan nilai (CKPN) atau loan loss allowances (LLA). Diskresi atas nilai wajar kredit (DAKRD) ini merupakan penetapan risiko default yang dilakukan manajer bank saat terjadi peningkatan risiko kredit macet dan terjadi penurunan nilai wajar kredit (Oktaviyanti, 2013).

Nilai DAKRD dalam penelitian ini diperoleh menggunakan pendekatan perhitungan yang digunakan dalam penelitian Oktaviyanti (2013) sebagai berikut:

LLA $_{\text {it }=} \propto+\mathbf{X}_{1} \operatorname{LOAN}_{\mathrm{it}}+\mathbf{X}_{2} \mathbf{N P L}_{\mathrm{it}}+$ $\mathbf{X}_{3} \Delta \mathrm{NPL}_{\mathrm{it}-1}+\varepsilon_{\mathrm{it}}$

Keterangan:

LLA $_{\text {it }}$ : Loan Loss Allowance bank konvensional dan syariah pada tahun $t$ diskala dengan total aset awal tahun

LOAN $_{i t}$ : Loan Outstanding (pinjaman beredar) bank konvensional dan syariah pada tahun $\mathrm{t}$ diskala dengan total aset awal tahun

NPL : Non Performing Loan (pinjaman bermasalah) bank konvensional dan syariah pada tahun t diskala dengan total aset awal tahun

$\Delta \mathrm{NP}_{\mathrm{Lit}-1}$ : perubahan non performing loan tahun $\mathrm{t}$ dengan non performing loan tahun t-1 diskala dengan total aset awal tahun

$\varepsilon_{\text {it }} \quad$ : error term atau DAKRD (diskresi nilai wajar kredit)

Menurut Untoro (2012), Budiarti (2012), Oktaviyanti (2013) volatilitas laba diduga menjadi penyebab manajer bank menggunakan diskresinya dalam penentuan nilai CKPN atau penyisihan kerugian. Masing-masing bank memiliki kebijakan tersendiri dalam pembentukan cadangan tersebut. Model yang digunakan untuk menguji hipotesis 1a dan $1 \mathrm{~b}$ mengenai pengaruh volatilitas laba terha- 
dap diskresi merujuk pada modifikasi model penelitian Oktaviyanti (2013) sebagai berikut:

$$
\begin{aligned}
& \text { DAKRD }_{\text {it }=} \propto+\alpha_{1} \mathrm{VOL}_{\mathrm{i}}+\alpha_{2} \mathrm{LLA}_{i t}+ \\
& \alpha_{3} \mathrm{IB}+\boldsymbol{\alpha}_{4} \mathrm{VOL}_{\mathrm{it}}{ }^{*} \mathrm{IB}+\alpha_{5} \mathrm{SIZE}_{\mathrm{it}}+\varepsilon_{\mathrm{it} . .(2)}
\end{aligned}
$$

\section{Keterangan:}

DAKRD $_{\text {it }}$ : Diskresi nilai wajar kredit bank konvensional dan syariah pada tahun $\mathrm{t}$ diskala dengan total aset awal tahun

Voli : tingkat volatilitas laba bank syariah dan konvensional, diukur dengan standar deviasi ROA bank periode 2007-2014

LLA $_{\text {it }}$ : Loan Loss Allowance atau CKPN diskala dengan total aset

IB : Variabel dummy, bernilai 1 untuk bank syariah, dan 0 untuk bank konvensional

SIZE $_{i t}$ : Ukuran aset bank syariah dan konvensional diukur dengan logaritma natural total aset

$\mathcal{E}_{\text {it }} \quad$ : error term

Hipotesis 1a diuji dengan melihat signifikansi VOL terhadap DAKRD (koefisien $\alpha 1$ ), sedangkan hipotesis $1 \mathrm{~b}$ diuji dengan melihat signifikansi VOL *IB (koefisien $\alpha 4$ ) terhadap DAKRD. Volatilitas dikatakan berpengaruh terhadap diskresi nilai wajar kredit jika hasil regresi variabel VOL terhadap DAKRD menunjukkan nilai yang signifikan $(p$-value $<\alpha)$. Diskresi nilai wajar kredit diduga turut dipengaruhi oleh faktor lain seperti ukuran aset dan tingkat CKPN. Penelitian ini tidak memberikan arah prediksi atas koefisien $\alpha 1$ dan $\alpha 4$ disebabkan dalam penelitian ini ingin diketahui arah hubungan volatilitas laba terhadap diskresi manajemen. Untuk menguji hipotesis $2 \mathrm{a}$ dan $2 \mathrm{~b}$ mengenai perataan laba di sektor perbankan, digunakan modifikasi model dalam penelitian Taktak et al. (2010) berikut ini:

$$
\begin{aligned}
L L P_{i t=} & \beta+\beta_{1} E B T_{i t}+\beta_{2} I B+\beta_{3} E B T_{i t}{ }^{*} I B+ \\
& \beta_{4} S I Z E_{i t}+\varepsilon_{i t} \ldots \ldots \ldots \ldots \ldots \ldots \ldots \ldots \ldots \ldots \ldots . . .
\end{aligned}
$$

Keterangan:

LLP $_{\text {it }}$ : Beban penyisihan kerugian aset produktif bank

EBT $_{\text {it }}$ :Laba sebelum pajak bank

IB : Variabel dummy, bernilai 1 untuk bank syariah, dan 0 untuk bank konvensional

$\mathrm{SIZE}_{\mathrm{i}}$ : Ukuran aset bank syariah dan konvensional diukur dengan logaritma natural total aset

$\varepsilon_{\mathrm{it}} \quad$ : error term
Hipotesis 2a diuji dengan melihat signifikansi EBT terhadap LLP (koefisien $\beta 1$ ), sedangkan hipotesis $2 \mathrm{~b}$ diuji dengan melihat signifikansi EBT $^{*}$ IB terhadap LLP (koefisien $\beta 3$ ). EBT merupakan variabel yang digunakan sebagai proxy atas praktik perataan laba pada penelitianpenelitian terdahulu (Wahlen, 1994; Collins dan Wahlen, 1995; Anandarajan et al., 2006; Taktaket al., 2010; Othman dan Mersni, 2014). Hipotesis 2a dan 2b terbukti jika EBT signifikan terhadap LLP. Pengujian ini tidak memberikan arah terhadap prediksi nilai koefisien $\beta 1$ dan $\beta 3$ disebabkan hasil penelitian yang belum konklusif pada penelitian terdahulu.

Pengujian pada hipotesis 3, mengenai peranan CG terhadap perataan laba, diuji menggunakan modifikasi model dalam penelitian Taktak et al. (2010) berikut ini:

$$
\begin{gathered}
L L P_{i t=} \gamma+\gamma_{1} \mathrm{EBT}_{i t}+\gamma_{2} \mathrm{CG}_{i t}+ \\
\gamma_{3} \mathrm{EBT}_{i t}{ }^{*} \mathrm{CG}_{i t}+\gamma_{4} \mathrm{SIZE}_{i t}+\varepsilon_{i t}
\end{gathered}
$$

Untuk menguji hipotesis 4 mengenai pelaksanaan CG di bank syariah yang lebih efektif memperlemah perataan laba, digunakan modifikasi atas model (4), berikut ini:

$$
\begin{aligned}
& L L P_{i t=\gamma}+\gamma_{1} \mathrm{EBT}_{i t}+\gamma_{2} \mathrm{CG}_{i t}+ \\
& \gamma_{3} \mathrm{EBT}_{i t}{ }^{*} \mathrm{CG}_{i t}+\gamma_{4} \mathrm{EBT}_{i t}{ }^{*} \mathrm{IB}^{*} \mathrm{CG}_{i t}+ \\
& \gamma_{5} \mathrm{SIZE}_{i t}+\varepsilon_{i t}
\end{aligned}
$$

Keterangan:

LLP $_{\text {it }}$ : Beban penyisihan kerugian aset produktif bank

EBT $_{\text {it }}$ :Laba sebelum pajak bank

CG : Skor pelaksanaan CG hasil self assessment bank

SIZE : Ukuran aset bank syariah dan konvensional diukur dengan logaritma natural total aset

IB : Variabel dummy, bernilai 1 untuk bank syariah, dan 0 untuk bank konvensional

$\varepsilon_{\mathrm{it}} \quad$ : error term

Hipotesis 3 diuji dengan melihat signifikansi EBT $^{*}$ CG terhadap LLP (koefisien $\gamma 3$ ), sedangkan hipotesis 4 diuji dengan melihat signifikansi $\mathrm{EBT}^{*} \mathrm{IB}^{*} \mathrm{CG}$ terhadap LLP (koefisien $\gamma 4$ ). Pelaksanaan CG terbukti dapat memperlemah praktik perataan laba, jika koefisien $\gamma 3$ bernilai positif signifikan. Pelaksanaan CG pada bank syariah dikatakan lebih efektif dalam memperlemah perataan laba jika koefisien $\gamma 4$ bernilai positif 
signifikan. Nilai koefisien $\gamma 3$ dan $\gamma 4$ diprediksi memiliki arah positif karena sesuai dengan peringkat dalam skor self-assessment CG yang menunjukkan jika skor yang lebih kecil memiliki peringkat yang makin baik. Sebaliknya, semakin besar skor self-assessment menunjukkan peringkat pelaksanaan CG yang lebih rendah. Dalam moderasi CG dengan EBT, diprediksi akan terjadi hubungan yang searah (positif), semakin kecil skor self-assessment, semakin kecil pula tingkat perataan laba, atau dengan kata lain memperlemah perataan laba.

\section{Uji Asumsi Klasik}

Menurut (Nachrowi dan Usman, 2006), estimasi regresi menggunakan data panel dapat dilakukan dengan tiga pendekatan yaitu Pooled Least Square Model, Fixed Effect Model, dan Random Effect Model. Pengujian pemilihan model menggunakan Chow Test, Haussman Test, dan LM Test menunjukkan jika model dalam penelitian ini paling tepat dilakukan dengan pooled-unbalanced least square model. Uji heteroskedastisitas pada seluruh model menggunakan White General Heteroscedasticity Test menunjukkan jika probabilitas melebihi 0,05, sehingga model tidak memiliki masalah heteroskedastisitas. Pengujian multikolinearitas dilakukan dengan melakukan analisis korelasi model untuk mengetahui nilai Variance Inflation Factor (VIF) dan Tolerance. Menurut (Nachrowi dan Usman, 2006), jika nilai VIF sama dengan atau lebih besar dari 1 dan tidak lebih dari 10, serta Tolerance menunjukkan nilai mendekati 1 maka variabel independen tidak berkorelasi satu dengan yang lain. Hasil pengujian menunjukkan jika VIF pada korelasi variabel independen lebih besar dari 1 dan tidak melebihi 10. Demikian juga dengan nilai tolerance yang menunjukkan nilai mendekati 1 untuk seluruh variabel independen. Dengan demikian, maka dapat disimpulkan tidak terdapat multikolinearitas pada model.

\section{HASIL DAN PEMBAHASAN}

\section{Statistik Deskriptif}

Berdasarkan Tabel 2 panel A dan panel B, rata-rata LLP bank syariah sebesar minus $2 \%$ dari total aset, sedangkan biaya penyisihan kerugian di bank konvensional minus 8.33 kali total aset. hal ini menunjukkan penggunaan biaya provisi kerugian pada bank konvensional lebih besar dibandingkan dengan bank syariah. Sedangkan nilai rata-rata EBT pada bank syariah sebesar 9\%, dengan nilai minimum minus $2 \%$ dan maksimum 3,6 kali dari total aset, dan nilai rata-rata EBTP bank konvensional sebesar $74 \%$ kali dari total aset dengan nilai minimum minus $2 \%$ dan maksimum 27.4 kali dari total aset. Pada bank syariah, nilai rata-rata volatilitas laba sebesar 1.76 , sedangkan nilai rata-rata volatilitas laba pada bank konvensional sebesar 1.13.

Tabel 2. Statistik Deskriptif

\begin{tabular}{|c|c|c|c|c|c|c|c|}
\hline \multicolumn{8}{|c|}{ Panel A: Statistik Deskriptif Bank Syariah } \\
\hline & LLP & EBTP & Vol & LLA & CG & Size & $\mathrm{Ib}$ \\
\hline $\min$ & -0.02 & -0.02 & 1.42 & 0.00 & 1.00 & 1974947633 & 0 \\
\hline $\max$ & 1.85 & 3.60 & 4.23 & 0.09 & 3.00 & $6.69 \mathrm{E}+13$ & 1 \\
\hline mean & 0.04 & 0.09 & 1.76 & 0.01 & 1.79 & $9.76 \mathrm{E}+12$ & 0.5 \\
\hline stdev & 0.24 & 0.50 & 0.47 & 0.01 & 0.37 & $1.48 \mathrm{E}+13$ & 0.5 \\
\hline \multicolumn{8}{|c|}{ Panel B: Statistik Deskriptif Bank Konvensional } \\
\hline & LLP & EBTP & Vol & LLA & CG & Size & \\
\hline $\min$ & -8.33 & -0.02 & 0.59 & -0.46 & 1.00 & $3.58 \mathrm{E}+11$ & \\
\hline $\max$ & 0.03 & 27.43 & 1.56 & 1.21 & 3.00 & $8.55 \mathrm{E}+14$ & \\
\hline mean & -0.16 & 0.74 & 1.13 & 0.08 & 1.62 & $2.04 \mathrm{E}+14$ & \\
\hline stdev & 1.04 & 4.18 & 0.16 & 0.27 & 0.44 & $2.14 \mathrm{E}+14$ & \\
\hline LLP & \multicolumn{7}{|c|}{ : Biaya Penyisihan Kerugian (dibagi total aset) } \\
\hline EBT & \multicolumn{7}{|c|}{ : Laba Sebelum Pajak (dibagi total aset) } \\
\hline Vol & \multicolumn{7}{|c|}{ : Volatilitas Laba } \\
\hline LLA & \multicolumn{7}{|c|}{ : Cadangan Kerugian Penurunan Nilai (dibagi total aset) } \\
\hline IB & \multicolumn{7}{|c|}{ : Variabel dummy, 1 bank syariah, 0 bank konvensional } \\
\hline $\mathrm{CG}$ & \multicolumn{7}{|c|}{ : Skor hasil self-assessment CG } \\
\hline SIZE & \multicolumn{7}{|c|}{ : Total Aset } \\
\hline
\end{tabular}


Tabel 3. Korelasi Antar Variabel

\begin{tabular}{|c|c|c|c|c|c|c|c|}
\hline & & EBT & VOL & LLA & IB & CG & SIZE \\
\hline \multirow[t]{2}{*}{ EBT } & Pearson Correlation & 1 &,- 090 &,- 054 &,- 105 &,- 178 &,- 297 \\
\hline & Sig. (2-tailed) & & ,337 &, 568 & ,261 & ,055 &, 001 \\
\hline \multirow[t]{2}{*}{ VOL } & Pearson Correlation &,- 090 & 1 &,- 167 &, $868^{*}$ & $188^{\circ}$ &,$- 607^{\cdots}$ \\
\hline & Sig. (2-tailed) & 337 & &, 075 &, 000 &, 043 &, 000 \\
\hline \multirow[t]{2}{*}{ LLA } & Pearson Correlation &,- 054 &,- 167 & 1 &,- 154 &,- 301 & $275^{\prime \prime}$ \\
\hline & Sig. (2-tailed) & ,568 &, 075 & &, 102 & ,001 & ,003 \\
\hline \multirow[t]{2}{*}{ IB } & Pearson Correlation &,- 105 & ,868“ &,- 154 & 1 & 205 &,- 752 \\
\hline & Sig. (2-tailed) & ,261 &, 000 &, 102 & & ,027 &, 000 \\
\hline \multirow[t]{2}{*}{$\overline{\mathrm{CG}}$} & Pearson Correlation &,- 178 & 188 &,$- 301^{\prime \prime}$ & $205^{\circ}$ & 1 &,- 296 \\
\hline & Sig. (2-tailed) &, 055 &, 043 &, 001 & ,027 & &, 001 \\
\hline \multirow[t]{2}{*}{ SIZE } & Pearson Correlation &,- 297 &,- 607 &, $275^{\prime \prime}$ &,- 752 &,- 296 & 1 \\
\hline & Sig. (2-tailed) & ,001 &, 000 &, 003 &, 000 &, 001 & \\
\hline \multicolumn{8}{|c|}{${ }^{*}$ " Correlation is significant at the 0.01 level (2-tailed). } \\
\hline \multicolumn{8}{|c|}{${ }^{*}$ Correlation is significant at the 0.05 level (2-tailed). } \\
\hline LLP & \multicolumn{7}{|c|}{ : Biaya Penyisihan Kerugian (dibagi total aset) } \\
\hline EBT & \multicolumn{7}{|c|}{ : Laba Sebelum Pajak (dibagi total aset) } \\
\hline Vol & \multicolumn{7}{|l|}{ : Volatilitas Laba } \\
\hline LLA & \multicolumn{7}{|c|}{ : Cadangan Kerugian Penurunan Nilai (dibagi total aset) } \\
\hline IB & \multicolumn{7}{|c|}{ : Variabel dummy, 1 untuk bank syariah, 0 untuk bank konvensional } \\
\hline $\mathrm{CG}$ & \multicolumn{7}{|c|}{ : Skor hasil self-assessment $\mathrm{CG}$} \\
\hline $\mathrm{SIZE}$ & \multicolumn{7}{|l|}{ : Log Total Aset } \\
\hline
\end{tabular}

Tabel 4. Pengujian Hipotesis $1 \mathrm{a}$ dan $1 \mathrm{~b}$

\begin{tabular}{|c|c|c|c|c|}
\hline \multicolumn{3}{|c|}{ Keterangan } & \multicolumn{2}{|c|}{ Hasil Pengujian Model 2} \\
\hline Variable & Koefesien & Prediksi & Coefficient & Sig. \\
\hline $\mathrm{C}$ & & & -0.0601 & 0.2163 \\
\hline $\mathrm{VOL}$ & $\alpha_{1}$ & $(+) /(-)$ & 0.0464 & 0.0002 \\
\hline LLA & & & 0.9027 & 0.1700 \\
\hline IB & & & -0.0014 & 0.3847 \\
\hline $\mathrm{VOL}^{*} \mathrm{IB}$ & $\alpha_{4}$ & $(+) /(-)$ & & 0.4576 \\
\hline $\mathrm{SIZE}$ & & & 0.9027 & 0.7087 \\
\hline Dependent Variable & & & & DAKRD \\
\hline Adjusted R-squared & & & & 0.138 \\
\hline F-statistic & & & & 6.898 \\
\hline Prob(F-statistic) & & & & 0.0002 \\
\hline Vol & : Volatilitas & & & \\
\hline LLA & : Cadangan & an Penur & agi total ase & \\
\hline IB & : Variabel $d t$ & 1 untuk & untuk bank & onal \\
\hline $\mathrm{SIZE}$ & : Log Total & & & \\
\hline
\end{tabular}

Nilai rata-rata besarnya penyisihan kerugian (LLA) pada bank syariah sebesar $1.5 \%$, sementara penyisihan kerugian bank konvensional menunjukkan nilai $8 \%$ dari total aset. Pada bank syariah, nilai rata-rata CG sebesar 1,79, sementara bank konvensional sebesar 1,62. Nilai yang lebih kecil mengindikasikan peringkat yang lebih baik. Berdasarkan nilai rata-rata ini, bank konvensional memiliki peringkat skor self-assessment CG yang lebih baik dibanding bank syariah. Nilai rata-rata aset pada bank konvesional sebesar Rp 2.035 trilyun sementara pada bank syariah $\mathrm{Rp} 9.76$ milyar. Terdapat perbedaan yang cukup besar disebabkan bank konvensional lebih dahulu dan cukup lama beroperasi, sementara bank syariah relatif baru beroperasi. Otoritas Jasa Keuangan juga menyebutkan jika ukuran aset bank syariah tidak melebihi $5 \%$ dari total aset perbankan nasional (Road Map Perbankan Syariah, 2015).

Berdasarkan Tabel 3, korelasi antara EBT dan SIZE menunjukkan nilai yang signifikan dengan arah negatif. Korelasi CG dan VOL menunjukkan hasil yang signifikan. Semakin tinggi skor CG (yang menunjukkan peringkat yang lebih rendah), berhubungan dengan meningkatnya volatilitas laba. Korelasi antara CG dengan LLA 
menunjukkan nilai yang negatif signifikan. Korelasi antara variabel IB dan CG menunjukkan nilai positif signifikan. Semakin besar aset bank, semakin baik pelaksanaan CG yang ditunjukkan oleh korelasi SIZE dan CG yang bernilai negatif signifikan.

\section{Hasil Pengujian Hipotesis}

Hasil pengujian model 2 untuk menjawab hipotesis $1 \mathrm{a}$ dan $1 \mathrm{~b}$ terdapat pada Tabel 4 . Berdasarkan hasil pengujian, koefisien $\alpha 1$ memiliki nilai signifikansi positif dan variabel VOL berpengaruh positif terhadap DAKRD. Dengan demikian, dapat dismpulkan bahwa semakin besar volatilitas laba maka akan semakin besar diskresi manajemen. Hal ini menunjukkan jika volatilitas laba berpengaruh terhadap diskresi manajemen dalam menentukan besarnya cadangan penyisihan kerugian. Diskresi manajemen digunakan untuk meminimalisir efek dari volatilitas laba yang dapat mempengaruhi kualitas dan keakuratan prediksi laba oleh para pengguna laporan keuangan (Defond dan Hung, 2003; Dichev, et al., 2006; Clubb dan Wu, 2012; Farook et al., 2014). Hasil ini konsisten dengan penelitian terdahulu yang membuktikan jika volatilitas laba berpengaruh terhadap diskresi manajemen (Untoro, 2012; Oktaviyanti, 2013). Berdasarkan hasil pengujian ini, hipotesis 1a diterima.

Berbeda dengan hasil pengujian pada hipotesis 1a, koefisen $\alpha 4$ dalam pengujian model 2 pada Tabel 4, tidak menunjukkan hasil yang signifikan. Variabel VOL* IB tidak signifikan terhadap DAKRD. Berdasarkan hasil pengujian ini, hipotesis $1 \mathrm{~b}$ tidak diterima, serta dapat dikatakan bahwa volatilitas laba tidak berpengaruh pada diskresi manajer bank syariah. Hal yang mungkin menjadi penyebab kondisi ini adalah adanya penundaan pemberlakuan CKPN di bank syariah. Sesuai dengan SE BI No. 11/ 33 /DPNP tanggal 8 Desember 2009, seluruh bank umum wajib menggunakan CKPN dalam pembuatan cadangan penyisihan kerugian. Namun, untuk bank syariah pelaksanaan penggunaan CKPN ini ditunda melalui SE BI No. 15/26/DPbS, tanggal 10 Juli 2013, yang mewajibkan bank syariah menggunakan CKPN paling lambat pada Januari 2015.

Penelitian Laela (2012) menggunakan proxy arus kas saat ini (current operating income) sebagai variabel yang diduga mempengaruhi kualitas laba bank. Penelitian tersebut memberikan bukti jika current operating income tidak berpengaruh terhadap kualitas laba bank. Penelitian ini berusaha memberikan temuan riset baru dengan menggunakan proxy prediktabilitas laba berupa volatilitas laba yang diduga dapat mempengaruhi kualitas laba (DeFond dan Hung, 2003; Dichev dan Tang, 2006; Clubb dan Wu, 2012; Untoro, 2012; Anggraita, 2012; Oktaviyanti, 2013). Pengujian pada hipotesis 1a dan $1 \mathrm{~b}$ mengenai volatilitas laba memberikan bukti bahwa volatilitas laba dapat digunakan sebagai proxy variabel yang mempengaruhi prediktabilitas laba. Hal ini diharapkan dapat menambah khasanah bukti penelitian terkait dengan proxy prediktabilitas laba yang diduga dapat mempengaruhi kualitas laba.

Meskipun terdapat perbedaan hasil pengujian antara hipotesis $1 \mathrm{a}$ dan $1 \mathrm{~b}$, terdapat kemungkinan jika volatilitas laba bank syariah juga dapat mempengaruhi diskresi manajemen dalam menentukan besaran nilai wajar kredit/pembiayaan. Hal ini disebabkan adanya peraturan BI yang menunda penggunaan CKPN di bank syariah membuat bank konvensional yang lebih dahulu menggunakan CKPN yang berbasis fair value, kemungkinan memiliki volatillitas laba yang lebih tinggi dibanding bank syariah. Selain itu, sebagian besar transaksi pada perbankan syariah di Indonesia dilakukan dengan akad jual beli (murabahah). Pada akad ini, keuntungan (margin) yang diperoleh bank syariah lebih dapat dipastikan, berbeda dengan akad bagi hasil (mudharabah) yang dapat menyebabkan fluktuasi keuntungan. Pada akad mudharabah, bagi hasil ditentukan oleh besarnya keuntungan/kerugian yang terjadi, sehingga tingkat fluktuasi keuntungan dapat menjadi lebih tinggi (Suhardiman, 2013).

Hipotesis 2a dan 2b diuji menggunakan Model 3. Hasil pengujian terdapat pada Tabel 5 . Hasil pengujian menunjukkan jika koefisien $\beta 1$ dan $\beta 3$ sama-sama memiliki nilai yang signifikan, namun dengan arah yang berbeda. Koefisien $\beta 1$ menunjukkan nilai negatif signifikan. Hasil pengujian menunjukkan jika EBT berpengaruh negatif terhadap LLP. Hal ini mengindikasikan jika biaya penyisihan kerugian akan menurun pada saat laba tinggi, dan biaya penyisihan akan meningkat pada saat laba rendah. Melalui hasil pengujian hipotesis 2 a mengenai penggunaan LLP sebagai cara perataan laba terbukti pada bank konvensional, dijelaskan bahwa arah signifikansi pada pengujian hipotesis $2 \mathrm{a}$ ini berbeda dengan hasil pengujian pada penelitian terdahulu yang menemukan bukti adanya hubungan positif antara LLP dan laba sebelum pajak (Wahlen, 1994; Kim dan Kross, 1998; Anandarajan, 2006; Taktak et 
al., 2010; Adzis, 2012; Bushman dan Williams, 2012). Hal ini diduga akibat adanya volatilitas laba yang terbukti pada pengujian hipotesis 1a sebelumnya, yang mempengaruhi diskresi manajer untuk menghasilkan laba yang relatif stabil (smooth).

Pada pengujian hipotesis $2 \mathrm{~b}$, koefisen $\beta 3$ bernilai positif signifikan. LLP berkorelasi positif dengan EBT. Hasil pengujian menunjukkan jika hipotesis 2b diterima. Dengan kata lain, LLP digunakan sebagai cara perataan laba pada bank syariah. Ketika laba sebelum pajak tinggi, maka biaya penyisihan kerugian juga akan tinggi. Hal ini sesuai dengan penelitian Farook et al. (2014) yang membuktikan adanya hubungan positif antara LLP dan EBT pada bank syariah.

Tabel 5. Hasil Pengujian Hipotesis 2a dan 2b

\begin{tabular}{|c|c|c|c|c|}
\hline \multicolumn{3}{|c|}{ Keterangan } & \multicolumn{2}{|c|}{ Hasil Pengujian Model 3} \\
\hline Variable & Koefesien & Prediksi & Coefficient & Sig. \\
\hline $\mathrm{C}$ & & & -0.9641 & 0.4250 \\
\hline EBT & $\beta_{1}$ & $(+) /(-)$ & -0.2051 & 0.0000 \\
\hline IB & & & 0.1121 & 0.4406 \\
\hline $\mathrm{EBT}^{*} \mathrm{IB}$ & $\beta_{3}$ & $(+) /(-)$ & 0.2187 & 0.0790 \\
\hline SIZE & & & 0.0293 & 0.4285 \\
\hline Dependent Variabl & & & & LLP \\
\hline Adjusted R-squarec & & & & 0.7167 \\
\hline F-statistic & & & & 7.376 \\
\hline Prob(F-statistic) & & & & 0.0000 \\
\hline LLP & Biaya Penyi & erugian $p$ & $\mathrm{t}$ (dibagi tot & \\
\hline EBT & Laba Sebely & $\mathrm{k}$ periode & agi total aset & \\
\hline IB & Variabel $d u$ & untuk ba & riah, 0 untul & onal \\
\hline SIZE & Log Total A & & & \\
\hline
\end{tabular}

Tabel 6. Hasil Pengujian Hipotesis 3 dan 4

\begin{tabular}{|c|c|c|c|c|c|c|}
\hline \multicolumn{3}{|c|}{ Keterangan } & \multicolumn{2}{|c|}{ Hasil Uji Model 4 (H3) } & \multicolumn{2}{|c|}{ Hasil Uji Model 5 (H4) } \\
\hline Variabel & Koef & Prediksi & Coefficient & Sig. & Coefficient & Sig. \\
\hline $\mathrm{C}$ & & & -0.2942 & 0.7097 & -13115 & 0.3453 \\
\hline EBT & & & -0.4467 & 0.0016 & -0.2021 & 0.0000 \\
\hline $\mathrm{CG}$ & & & 0.0310 & 0.7698 & 0.1295 & 0.3868 \\
\hline $\mathrm{EBT}^{*} \mathrm{CG}$ & $\gamma_{3}$ & $(+)$ & 0.2151 & 0.0854 & & \\
\hline IB & & & & & 0.0556 & 0.6090 \\
\hline $\mathrm{EBT}^{*} \mathrm{IB}^{*} \mathrm{CG}$ & $\gamma_{4}$ & $(+)$ & & & 0.1024 & 0.0856 \\
\hline SIZE & & & 0.0076 & 0.7343 & 0.0372 & 0.3551 \\
\hline \multicolumn{3}{|c|}{ Dependent Variable } & \multicolumn{2}{|c|}{ LLP } & \multicolumn{2}{|c|}{ LLP } \\
\hline \multicolumn{3}{|c|}{ Adjusted R-squared } & \multicolumn{2}{|c|}{0.7167} & \multicolumn{2}{|c|}{0.7148} \\
\hline \multicolumn{3}{|l|}{ F-statistic } & \multicolumn{2}{|c|}{7.376} & \multicolumn{2}{|c|}{5.867} \\
\hline \multicolumn{3}{|l|}{ Prob(F-statistic) } & \multicolumn{2}{|c|}{0.0000} & \multicolumn{2}{|c|}{0.0000} \\
\hline
\end{tabular}

\begin{tabular}{ll}
\hline LLP & : Biaya Penyisihan Kerugian periode t (dibagi total aset) \\
EBT & $:$ Laba Sebelum Pajak periode t (dibagi total aset) \\
& : Skor hasil self-assessment CG (semakin rendah skor, maka semakin baik \\
IB & : Veringkat CG) \\
SIZE & $:$ Log Total Aset
\end{tabular}

Tabel 7. Uji Beda Mean Variabel skor hasil self-assessment CG - Independent Samples Test

\begin{tabular}{ccccccc}
\hline & & \multicolumn{2}{c}{ Levene's Test for } & \multicolumn{2}{c}{ t-test for Equality of Means } \\
\hline & & $\mathrm{F}$ & Sig. & $\mathrm{t}$ & $\mathrm{df}$ & Sig. (2-tailed) \\
\hline CG & Equal variances assumed & 2,660 &, 106 & 2,238 & 114 & $0,027^{*}$ \\
& Equal variances not assumed & & & 2,290 & 112,576 & $0,024^{*}$ \\
\hline Mean & Bank Syariah & & & 1,79 & & \\
CG Score & Bank Konvensional & & & 1,62 & & \\
\hline
\end{tabular}


LLP yang meningkat digunakan untuk meratakan laba ketika terdapat surplus dari bagi hasil investasi kepada nasabah. Lebih lanjut, Laela (2012) berpendapat jika bank syariah akan mencadangkan laba untuk meratakan tingkat pengembalian dan secara sukarela mengurangi laba untuk meningkatkan return pada nasabah. Namun demikian, perataan laba pada bank syariah harus dilakukan sesuai dengan ketentuan fatwa DSN-MUI No. 87/DSN-MUI/XII/2012. Perataan laba hanya dapat dilakukan jika terdapat selisih lababank syariah yang melebihi tingkat imbalan atau hasil yang diestimasi pada akad bagi hasil dana mudharabah (muthlaqah) dan pada simpanan dana nasabah menggunakan akad mudharabah muqayyadah.

Hasil pengujian model 4 untuk menguji hipotesis 3 terdapat pada Tabel 6. Hipotesis 3 diuji dengan melihat signifikansi $\mathrm{EBT}^{*} \mathrm{CG}$ terhadap LLP (koefisien $\gamma 3$ ). Hasil pengujian menunjukkan jika koefisien $\gamma 3$ bernilai positif signifikan. Semakin rendah skor CG (yang menunjukkan peringkat pelaksanaan CG yang lebih baik), semakin rendah pula tingkat perataan laba. Oktaviyanti (2013) membuktikan jika mekanisme CG yang tercermin melalui skor self-assessment mampu memperlemah volatilitas laba terhadap manajemen laba di sektor perbankan. Hasil ini menunjukkan jika hipotesis 3, yaitu pelaksanaan CG yang semakin baik akan memperlemah perataan laba terbukti.

Untuk menguji hipotesis 4, dilakukan pengujian pada model 5. Hipotesis 4 diuji dengan melihat signifikansi $\mathrm{EBT}^{*} \mathrm{IB}^{*} \mathrm{CG}$ terhadap LLP $\left(\right.$ koefisien $\gamma_{1}$ ). Hasil pengujian terdapat pada Tabel 6. Hasil pengujian menunjukkan koefisien $\gamma_{4}$ bernilai positif signifikan. Berdasarkan hasil ini, adanya double board pada struktur CG bank syariah mampu meningkatkan tingkat monitoring terhadap perataan laba. Keberadaan DPS yang bertugas memastikan berjalannya proses alokasi laba/rugi pada nasabah sesuai dengan hukum Islam, nampaknya cukup efektif dalam mengawasi dan mencegah tindakan perataan laba yang dilakukan oleh manajer (Laela, 2012).

\section{Analisis Tambahan}

Untuk menginvestigasi perbedaan pelaksanaan CG pada bank konvensional dan syariah, terutama dengan adanya DPS sebagai mekanisme tambahan pada bank syariah, dilakukan pengujian uji beda nilai rata-rata skor hasil self-assessment CG. Hasil pengujian yang terdapat pada Tabel 7 mengkonfirmasi adanya perbedaan nilai rata-rata skor self-assessment CG kedua bank. Adanya double board berupa DPS dan BoC pada bank syariah berpengaruh terhadap nilai rata-rata skor self-assessment CG. Namun demikian, berdasarkan nilai rata-rata skor self-assessment CG pada tabel statistik deskriptif, peringkat skor selfassessment CG bank syariah lebih rendah jika dibandingkan bank konvensional. Hal ini ditunjukkan dengan nilai rata-rata skor self-assessment CG bank syariah $(1,79)$ yang lebih besar dibandingkan bank konvensional $(1,62)$. Hasil ini mengindikasikan jika masih terdapat hal yang harus diperbaiki dalam pelaksanaan CG di bank syariah.

\section{SIMPULAN}

Berdasarkan pengujian yang telah dilakukan dapat disimpulkan bahwa volatilitas laba mempengaruhi diskresi manajemen dalam penentuan besarnya nilai cadangan kerugian penurunan nilai (CKPN) di bank konvensional. Pada bank syariah, volatilitas laba tidak mempengaruhi diskresi manajemen dalam penentuan CKPN atau cadangan penyisihan kerugian. Pada bank konvensional, diduga volatilitas laba dipengaruhi oleh adanya perubahan pada pengukuran dan pelaporan instrumen keuangan menggunakan nilai wajar. Volatilitas laba tidak terbukti berpengaruh pada diskersi akrual manajer bank syariah diduga disebabkan oleh adanya penundaan kewajiban penggunaan CKPN oleh Bank Indonesia dalam menghitung penyisihan kerugian. Selain itu, tidak terbuktinya volatilitas laba yang mempengaruhi diskresi akrual manajer juga diduga disebabkan oleh akad jual beli (murabahah) yang mendominasi transaksi operasional bank syariah, dimana tingkat keuntungan lebih dapat dipastikan dibandingkan pada akad bagi hasil (mudharabah).

Penelitian ini menemukan bukti jika terdapat perataan laba menggunakan biaya penyisihan kerugian (Loan Loss Provision/LLP) pada bank konvensional dan bank syariah dengan arah pengujian yang berbeda. Pada bank konvensional, LLP berpengaruh negatif terhadap laba sebelum pajak yang diduga berkaitan dengan adanya volatilitas laba akibat penghitungan CKPN meggunakan fair value. Pada bank syariah LLP berpengaruh positif terhadap laba sebelum pajak. Hal ini diduga disebabkan pelaksanaan kontrak bagi hasil yang menimbulkan insentif bagi manajer bank syariah melakukan tindakan perataan laba 
untuk menjaga kestabilan tingkat pengembalian pada nasabah. Lebih lanjut, penelitian ini juga membuktikan jika mekanisme CG yang tercermin melalui skor self-assessment mampu memperlemah tingkat perataan laba pada kedua sektor perbankan.

Berdasarkan hasil pengujian dalam penelitian ini, maka dapat disimpulkan bahwa kualitas laba bank syariah tidak dipengaruhi oleh volatilitas laba, namun dipengaruhi oleh perataan laba menggunakan LLP. Pada bank konvensional, kualitas laba dipengaruhi oleh volatilitas dan perataan laba menggunakan LLP. Keberadaan DPS menjadi pembeda yang terbukti signifikan mempengaruhi pelaksanaan CG di bank syariah jika dibandingkan dengan bank konvensional.

Implikasi dari hasil penelitian ini adalah perlunya kewaspadaan bagi manajer bank dan regulator, khususnya pada bank syariah mengenai peningkatan volatilitas laba. Pemberlakuan penghitungan cadangan kerugian menggunakan CKPN berbasis nilai wajar pada bank syariah yang efektif di tahun 2015 diprediksi turut meningkatkan volatilitas laba. Hal ini berdasarkan dampak penerapan CKPN terhadap pengaruh volatilitas laba terhadap kualitas laba pada bank konvensional (yang terlebih dahulu diwajibkan menerapkan CKPN) yang terbukti pada penelitian ini dan penelitian-penelitian terdahulu. Pada bank syariah, prediksi peningkatan volatilitas laba tersebut sebaiknya diantisipasi untuk meminimalisir dampak fluktuasi laba pada kualitas laba. Adanya dampak negatif peningkatan volatilitas laba yang dibuktikan dalam penelitian-penelitian terdahulu sebaiknya dapat diatasi oleh manajer bank syariah dengan semakin meningkatkan kuantitas informasi dan transparansi laporan keuangan, agar keakuratan prediksi laba tetap terjaga. Lebih lanjut, penelitian ini dapat menjadi alat evaluasi bagi nasabah dan regulator bahwa terdapat indikasi perataan laba pada bank konvensional dan syariah. Walaupun mekanisme CG terbukti mampu memperlemah tindakan tersebut, namun proses dan pelaksanaan self-assessment $\mathrm{CG}$ perlu tetap ditingkatkan.

\section{DAFTAR PUSTAKA}

Ahmed, A. S., C. Takeda dan S. Thomas. 1999. Bank Loan Loss Provisions: A ReExamination of Capital Management, Earnings Management, and Signaling
Effects. Journal of Accounting and Economics, 28, 1-25.

Anandarajan, A. M., I. Hasan dan Cornelia. 2006. The Use of Loan loss provisions for Capital Management, Earnings Management, and Signaling by Australian Banks. Discussion Papers. Bank of Finland Research.

Adzis, A. A. 2012. The Impact of International Financial Reporting Standard (IFRS) on Bank Loan Loss Provisioning Behavior and Bank Earnings Volatility. Doctoral Dissertation, Massey University of New Zealand

Barth, Mary E. W., R. Landsman, J. M. Wahlen 1995. Fair Value Accounting: Effect on Bank's Earning Volatility, Regulatory Capital, and Value of Contractual Cash Flow. Journal Banking and Finance, 577605

Bartov, E. 1993. The Timing of Asset Sales and Earning Manipulation, The Accounting Review, 68 (4), 840-855.

Budiarti, Age Estri (2012). PPAP menuju CKPN: Dampak terhadap kredit perbankan.http://blog.pasca.gunadarma.ac.i d/2012/05/29/ppap-menuju-ckpn-dampakterhadap-kredit-perbankan/

Bushman, R. M. dan C. D. William. 2012. Accounting Discretion, Loan loss provisioning, and Discipline of Bank's Risk Taking. Journal of Accounting and Economics, 54 (1), 1-18.

Clubb, C. dan G. Wu. 2014. Earnings Volatility and Earnings Prediction: Analysis and UK Evidence. Journal of Business Finance \& Accounting, 41 (1-2), 53-72.

Cornett, M. M., J. M. Jamie, dan T. Hassan. 2009. Corporate Governance and Earnings Management at Large U.S Banks Holding Companies. Journal of Corporate Finance, 412-430.

Dechow, P. M., C. M. Schrand dan E. Collins. 2004. Earnings Quality. USA: Research Foundation of CFA Institute.

Dechow, P., W. Ge dan C. Schrand. 2010. Understanding Earnings Quality : A Review of The Proxies, Their Determinants and Their Consequences. Journal of Accounting and Economics, 50 (2-3), 344401.

Defond, M. L. dan M. Hung. 2003. An Empirical Analysis of Analysts' Cash Flow. Journal of Accounting and Economics, 35, 73-100.

Dichev, I. D., S. M. Ross dan V. W. Tang. 2006. 
The Link Between Earnings Volatility And Earnings Predictability.

Elnahass, M., M. Izzeldin dan O. Abdelsalam. 2014. Loan loss provisions, Bank Valuations and Discretion: A Comparative Study Between Conventional and Islamic Banks. Journal of Economic Behaviour and Organization 103, S160-S173.

Farook, S., M. K. Hassan dan G. Clinch. 2014. Islamic bank incentives and discretionary loan loss provisions. Pacific-Basin Finance Journal, 28, 152-174.

Gujarati, D. N. 2004. Basic Econometrics. Fourth Edition. McGraw Hill Companies.

Haan, J. D. dan T. Poghosiyan. 2012. Bank size, Market Concentration, and Bank Earnings Volatility in US. Int.Fin.Markets, Inst. and Money, 35-54.

Kim, M. S. dan W. Kross. 1998. The Impact of The 1989 Change in Bank Capital Standards on Loan loss provisions and Loan Write-Offs. Journal of Accounting and Economics, 25, 66-99.

Laela, S. F. 2012. Kualitas Laba dan Corporate Governance: Benarkah Kualitas Laba Bank Syariah Lebih Rendah dari Bank Konvensional? Jurnal Akuntansi dan Keuangan Indonesia, 9 (1), 22-42.

Lo, K. 2008. Earnings Management and Earnings Quality, Journal of Accounting and Economics 45, 350-357.

Nachrowi, D. N. dan H. Usman. 2006. Pendekatan Populer dan Praktis Ekonometrika Untuk Analisis Ekonomi dan Keuangan. Jakarta: Lembaga Penerbit Fakultas Ekonomi Universitas Indonesia.

Oktaviyanti. 2013. Pengaruh Volatilitas Laba pada Manajemen Laba Perbankan dengan Moderasi Self Assesment Corporate Governance, Struktur Kepemilikan dan Kualitas Audit. Tesis, Universitas Indonesia.

Ben Othman, H dan H. Mersni. 2014. The Use of Discretionary Loan loss provisionby Islamic Banks and Conventional Banks in The Middle East Region. Studies in Economic and Finance, 31 (1), 106-128.

Rifka. 2015. CKPN Bank Syariah. April 14, 2015. www.rifkadejavu.com/CKPN Bank Syariah

Road Map Perbankan Syariah 2015-2019, Otoritas Jasa Keuangan.

Statistik Perbankan Syariah, Juni 2015. Otoritas Jasa Keuangan.
Suhardiman, C. 2013. Profit-Equalization Reserve, Mestikah? http://cecepmh.blogspot.co.id/2013/11/profit-equalizationreserve-mestikah.html

Taktak, N. B., B. S. Z Sarra dan B. Abdelkader. 2010. Do Islamic Banks Use Loan loss provisionTo Smooth their Result? Journal of Islamic Accounting and Business Research, 1 (2), 114-127.

Untoro. 2012. Perataan Laba Sebagai Respon Perbankan terhadap Implementasi Awal PSAK 50 (Revisi 2006) dan psak 55 (Revisi 2006) Melalui Penentuan Nilai Wajar Aset. Disertasi Doktoral, Universitas Indonesia.

Wahlen, J. M. 1994. The Nature of Information in Commercial Bank Loan Loss Disclosures. The Accounting Review, 9 (3), 455-478. 